\title{
Small and Medium Enterprises (SME's) Funding and Deposit Money Banks in Nigeria
}

\author{
Okere, Peter .A PhD ${ }^{1}$, Njoku, Gospel $\mathrm{O}^{2} \&$ Nwosu Eleazar $\mathrm{C}^{3}$ \\ ${ }^{l}$ Dept. of Banking and Finance Imo State Polytechnic, Umuagwo-Ohaji \\ ${ }^{2}$ Dept. of Banking and Finance, Imo State Polytechnic, Umuagwo-Ohaji \\ ${ }^{3}$ Dept. of Accountancy, Federal Polytechnic, Ukana, Akwa Ibom
}

\begin{abstract}
This study theoretically investigated the reasons why banks are reluctant in granting credit facilities to the Small and Medium Enterprises (SMEs) in Nigeria. The study identified the indispensable roles of SMEs as the most viable engine for job creation, economic growth and development, and the need for the development of the Small and Medium Scale Enterprise (SMEs) in Nigeria. Adopting the theoretical approach, the study observed that banks are willing and capable to provide the necessary funds needed by SMEs but so many factors have hampered them. SME operators are compelled to provide their own electricity, water and, in some cases access roads to offset deficiencies in public infrastructural facilities. This is detrimental to viability and efficiency in production and is considered as high risk by the banks. Banks as a business entity have to make profit and maintain enough liquidity needed to meet up with other obligations of other stakeholders. The inability of the deposit money banks to extend the needed credits to the SMEs is due the unfriendly environment in which these SMEs operate. This study therefore recommends that government should totally adopt the Indian Model of SMEs development. Again, the environment for doing in Nigeria should be improved by the government most especially the electricity generation, sustainable water supply, quality roads.
\end{abstract}

Keywords: Credit, Deposit Money Banks, Small and Medium Scale Enterprises (SMEs)

\subsection{Introduction}

The development of any economy of any nation is greatly dependent on the functionality and interplay of the Small and Medium Enterprises (SME's). For both developing and developed nations of the world, small and medium enterprises play very prominent roles in the process of industrialization and economic growth. Separately from rising per capita income and output, SMEs create service opportunities, enhance regional financial balance through business dispersal and generally promote effective resource utilization considered critical to engineering economic growth and development (Ogujiuba, Ohuche and Adenuga, 2004).

By the report of the United Nations Industrial Development Organization (UNIDO, 2012), SMEs have a significant role to play in economic development of any nation as they formed the backbone of the private sector; they make up over 90 percent of entrepreneurs of the world and account for 50 to 60 percent of employment generation; they also play an important role in poverty alleviation. In spite of the important role of SMEs to the development of Nigeria's economy, it is still been constrained by so many factors such as inadequate capital, stringent conditions on bank credit facility, poor management and faulty implementation of government policies on SME's which retards the development of the sector (Abiola, Iyoha, and Joseph, 2011 and Osotimehin, Jegede, Akinlabi and Olajide, (2012).

But, Berger and Udell (2001) further noted that not only the funding that adversely affects the small and scale enterprises, the harsh economic environment in which both the banks and SMEs operate can significantly affect the willingness and capability of banks to lend to small and medium scale enterprises. In this COVID-19 pandemic period where the whole world is confronted with this deadly virus that has led to total shutdown of businesses all over the globe, banks willingness to fund SMEs may be affected. It is expected that in this pandemic, 
loan repayment of SMEs might be irregular. This is the time government and the financial regulators need to act to avoid catastrophe in the economy ranging from loss of jobs, default in loan repayments and even close of up of some businesses.

Deposit money banks through their intermediation role are meant to provide the needed financial succor to SMEs to enable them operate optimally. Prior researchers have identified inadequate funding as a threat to the performance of SMEs (Berger and Udell, 2001, Onwuchekwa, Ochachosim and Ifeanyi, 2013, Osoba 1987, and Onugu, 2005). The inadequate funding of small and medium enterprises in Nigeria by the banks has prompted the entrepreneurs to seek and chase other sources of financing even at a higher exorbitant interest rates According to World Bank ICA survey 2006, small and medium enterprises are mostly is financed and managed by owners and relations. About $70 \%$ of the financing in most cases is normally provided by the owners. The owners experience difficulties in raising equity capital from the finance houses or individuals. Even when the economics home agrees to provide equity capital, the circumstances are always terrible. All these result to insufficient capital available to the sector and thus lead to poor finance. This is the bane of most small house business in Nigeria. About $80 \%$ of small and medium enterprises are quiet because of this problem of poor financing and other problems linked with it (Chukwuemeka, 2006). Banks in Nigeria have been accused of not providing enough funding for SMEs development in Nigeria, even when the regulatory authorities like Central Bank of Nigeria (CBN) have at various times mandated or appealed to the banks in Nigeria to increase their funding to SMEs, the trend has not changed.

Analysis of the annual trend in the share of deposit money banks credit to small-scale industries indicates a decline from about 7.5 per cent in 2003 to less than $1 \%$ in 2006 and a further decline in 2012 to 0.14 per cent (Sanusi, 2013). In 2015, the bank's total funding to SMEs declined from 17, 424.3 million naira to 12, 949 million naira in 2015. Banks are often reluctant to lend to SMEs because of the perceived risky nature of SMEs by them. It is important to investigate why banks pay little attention in granting of credit to SMEs in view of great potentials attributable to SMEs. If banks are statutorily established to play the intermediation role and make profit from this, why won't they grant huge funds to these catalysts of development called SMEs? Banks are business ventures of profit making is one of their objectives and SMEs, all things been equal should be a good business for banks to make huge profit.

In the light of the above, this paper appraises the reasons why banks in Nigeria are not keen or reluctant to extend more funds to SMEs and poses this question:

- What are the critical causes of the risk-averse behavior of banks in funding small and medium scale enterprises in

Nigeria?

Bringing all issues into good focus, there is a need to discuss the issue under four subsections. Section one introduces the topic; section two deals with literature reviews; section three discusses access to finance by SMEs in Nigeria and section concludes the study with some recommendations. This study focuses only on deposit money banks.

\subsection{Literature Review}

There is no unique definition of Small and Medium Scale Enterprises (SMEs) in Nigeria as in other economies of the world. SMEs in Nigeria are defined in the context of the following:

the size or amount of investment in assets

total annual turnover, and

. The number of employees

As a developing economy of the world, Nigeria with the introduction of the National Policy on SMEs has addressed the issue of definition as to what constitutes small and medium enterprises. The definition adopts a classification based on dual criteria, employment and assets (excluding land and buildings) as shown below. 
Table 1: Definition of SMEs in Nigeria

\begin{tabular}{|l|l|l|l|}
\hline S/no. & Size Category & Employment & Assets (Excluding Land and Building \\
\hline 1 & Small enterprises & 10 to 49 & 5 to less than 50 \\
\hline 2 & Medium enterprises & 50 to 199 & 50 to less than 500 \\
\hline
\end{tabular}

Source: SMEDAN (2010)

$>$ Small enterprise are those enterprise whose total assets (exclusive of land and building) are above 5 Million Naira but not more than 50 million naira with a total labor force of above ten, but not more than 40-9 worker.

$>$ Medium enterprise are those enterprise with total assets (exclusive of land and building) are above 50 million Naira, but not more than 500 Naira with a total labor force of between fifty and one hundred ninety nine workers.

SMEs are divided into Medium Scale Enterprise (MSE), Small Scale Enterprise (SSE) and Micro Enterprises (ME).The federal ministry of industries defines a Medium Scale Enterprise as any company with operating assets less than two hundred million and employing less than two hundred persons. A Small Scale venture on the other hand, is one that has total assets less than fifty million, with less than hundred workers. Yearly turnover is not careful in its definition of a SME. The National Economic Reconstruction Fund (NERFUND) defines a SSE as one whose total assets is less than ten million but made no orientation to either its yearly turnover or the number of worker (WORLD BANK,2010. Two basic financing concepts in the development of SMEs, the formal and informal forms of financing have been recognized by the previous researcher, scholars and practitioners(Gelinas, 1998; Aruwa, 2004).The findings were that among the most popular of the formal sources of financing, the deposit money banks and the development banks remains the formal sources of finance for enterprises.

\subsection{Central Bank of Nigeria (CBN) Interventions towards Stimulating the SMEs Sector in Nigeria.}

Government has made several policies in the past to support and promote the activities and operations of SMEs as a crucial sector of the economy which poor planning and fraudulent implementation by government servants did not allow to make an impact on the economy (Adewale, 2007). The SMEs sector has its own peculiar characteristics that made finances (deposit money banks) refuse to give credits to them as they are viewed as very serious credit risks.

The Various attempts made by Central Bank of Nigeria (CBN) to stimulate the growth and development of the SMEs sector in Nigeria include:

1. The Microfinance policy narrow and decision-making structure in Nigeria

2. The Small and Medium Enterprises Equity Investment scheme (SMEEIS)

3. The N200 Billion Small and Medium Scale Enterprises Guarantee Scheme (SMECGS)

4. The 200 Billion SME Restructuring / Refinancing Fund

5. Agricultural Credit Guarantee Scheme Fund (ACGSF)

6. Agricultural Credit Support Scheme (ACSS)

7. Entrepreneurship Development Centres (EDCs)

8. Micro, Small and Medium Enterprises Development Fund ( MSMEDF)

\subsection{Importance of Small and Medium Enterprises in Nigeria}

It is important to note that the development of entrepreneurs cannot be overemphasized and the role they play in economic development and how they are financed through both formal and informal sources. The development experience of many countries indicates that SMEs can meaningfully contribute to the attainment of many development objectives. These include output growth, service age group, even site of industry among region of the countries, income redeployment, promotion of native free enterprise and skill as well as manufacture of 
middle goods to strengthen inter and intra industrial leakages . Never the less, the extent to which the opportunities offered by SMEs are exploited and their contributions maximize in any economy depends on the enabling environment created through the provision of requisite infrastructures facilities such as roads, telecommunication, power etc. and pursuit of policies such as concretionary financing that give confidence and make stronger the growth of the sector. Although the credit of the economic significance of SMEs to the Nigerian economy is only a recent development, today the aids of the sector to the economy are no longer contestable.

Meyanathan (1994); Ukpabio(2004), Uzor (2004) and the World Bank (2001), all agreed that small and medium enterprises (SMEs) play middle role in the development of large scale enterprise. They reduce local disparity through the creation of service opportunity in the rural areas and rally local resources more readily than large-scale industry.

The deposit money banks provide the formal sources of finance to SMEs though mostly in short term lending. This is because most deposit money banks' deposits are subject to withdrawal on demand by the customers and therefore should be risky to lend out for a very long term or permanent financing. Most deposit money banks' interest on loans depends upon the level of interest rate in the economy, usually determined by the central Bank.

The financial system in Nigeria is not in short supply of liquidity anyway, but banks have been very reluctant to grant loans to SMEs, which they regard as a high-risk sector. Most of the banks would rather pay the penalty imposed for not meeting the minimum exposure to preferred sectors of the economy than actually run the risk of being exposed to them. Though the bank sector is the largest and most significant source of outside financing for small scale enterprise, by and large, it is believed to be under portion the needs of this sector. Small scale enterprises on the other hand draw financing from a variety of sources. Small firms leverage proportionally more on non-bank services such as internal funds (savings, reformed earning family network) and the informal sector (money lender) as a result of their incapability to produce the collateral needed by the deposit money banks (Salta, 2003).

Table 2: Deposit money banks total loans to small and medium scale enterprises

\begin{tabular}{|c|l|l|l|}
\hline & DBMs Loans & DBMs & DBMs Loans \\
\hline YEAR & To SMEs & Total Credit to Private & To SMEs as \\
\hline 1992 & $20,400.00$ & Sector $\left(\mathbf{N}^{\prime} \mathbf{M}\right)$ & \% of Total Credit (\%) \\
\hline 1993 & $15,462.90$ & $75,456.30$ & 27 \\
\hline 1994 & $20,552.50$ & $88,821.00$ & 17.4 \\
\hline 1995 & $32,374.50$ & $143,516.80$ & 14.3 \\
\hline 1996 & $42,302.10$ & $204,090.60$ & 15.9 \\
\hline 1997 & $40,844.30$ & $254,853.10$ & 16.6 \\
\hline 1998 & $42,260.70$ & $311,358.40$ & 13.1 \\
\hline 1999 & $46,824.00$ & $366,544.10$ & 11.5 \\
\hline 2000 & $44,542.30$ & $449,054.30$ & 10.4 \\
\hline 2001 & $52,428.40$ & $587,999.90$ & 7.6 \\
\hline 2002 & $82,368.40$ & $844,486.20$ & 6.2 \\
\hline 2003 & $90,176.50$ & $948,464.10$ & 8.7 \\
\hline 2004 & $54,981.20$ & $1,203,199.00$ & 7.5 \\
\hline 2005 & $50,672.60$ & $1,519,242.70$ & 3.6 \\
\hline 2006 & $25,713.70$ & $1,991,146.40$ & 2.5 \\
\hline
\end{tabular}




\begin{tabular}{|l|l|l|l|}
2007 & $41,100.40$ & $4,820,695.70$ & 0.9 \\
\hline 2008 & $13,512.20$ & $7,799,400.10$ & 0.2 \\
\hline 2009 & $16,366.50$ & $9,667,876.70$ & 0.2 \\
\hline 2010 & $12,550.30$ & $9,198,173.10$ & 0.1 \\
\hline 2011 & $15,611.70$ & $9,614,445.80$ & 0.2 \\
\hline 2012 & $13,863.50$ & $10,440,956.30$ & 0.1 \\
\hline 2013 & $15,353.00$ & $11,543,649.90$ & 0.1 \\
\hline 2014 & $17,424.30$ & $12,511,671.50$ & 0.1 \\
\hline 2015 & $12,949.50$ & $13,568,543.70$ & 0.1 \\
\hline 2016 & $12,047.90$ & $15,628,550.80$ & 0.1 \\
\hline 2017 & $79,227.40$ & $16,237,800.90$ & 0.5 \\
\hline
\end{tabular}

Source: CBN statistical bulletin, 2017

The above table shows the level of deposit money banks loans to small scale enterprises as percentage of total credit. The analysis focused on deposit money banks loans to entrepreneurs from 1992 to 2017. In 1992, the loan was $27 \%$. It declined to $14.3 \%$ in 1993 and continuously it declines to so a low level of $1 \%$ in 2006 and sluggishly increased to $5 \%$ in 2017. It seems that, the consolidation of the Nigerian banking industry on or before 31/12/2005 seems to have worsened the financial constraint of SMEs in Nigeria. The aftermath of the consolidation exercise between 2006 and 2012 shows an average of $0.41 \%$ to small business lending ((Babafemi, Adesheye and Akure, 2015). This trend did not change after full consolidation as it can be seen that between 2013 and 2017 an average of $.18 \%$ to small and medium enterprises.

\subsection{Models of Funding SMEs from other Countries}

\section{Indian Model:}

The basic principle guiding the funding of SMEs in India is that the government regards small business as the "eggs" that hatch big businesses. Apart from adequate incentives, the government supports SMEs by bulky purchasing their products and retailing them both for the domestic market and for exports. To make easy their access to bank credits, the government issues SMEs LPOs. Banks accept such contract papers as security. When small businesses bid for government contracts with big businesses, big ones must bid 15\% less than small businesses for them to supply government needs. Payments are promptly made to the SMEs and this encourages their growth.

\section{Bangladesh -The Gramen Model:}

Prof Yunus Mohammed developed the GRAMEN MODEL. In this model banks targets potential borrowers for its core operations and form them into groups. Then soft loans are made available to these SMEs, repayable within specific period before others in that strategic group can benefit from the scheme. With this system, there is a subtle pressure from other SMEs that are members of this strategic core on the benefiting group to repay so that others can benefit from the scheme. This has introduced healthy capitalization among SMEs in Bangladesh through factoring thes credibility of the borrowers.

\section{The Brazilian Model:}

The main thrust of the Brazillian model is that of the heavy funding and subsidies, the government provides infrastructures in an area and encourages the cluster of industries in such areas. The SINOS VALLEY shoe cluster industries in Brazil have revolutionalized the Brazilian shoe industry. For the past 30 years, over 500 SMEs that produce shoes are located there. Today Brazil is the world's third largest shoe exporter. 


\subsection{Empirical Review}

Ayuba andZubairu (2015) examined the impact of banking sector credit on the growth of small and medium enterprises in Nigeria between 1985 and 2010 using descriptive statistics, correlation matrix and error correction and the stud revealed that banking sector credit has significant impact on the growth of small and medium enterprises in Nigeria. Oke and Aluko, (2015) examined the impact of deposit money banks in financing small and medium scale enterprises (SMEs) in Nigeria between 2002 and 2012. A sample of ten (10) deposit money banks is drawn for the study and individual bank data and macroeconomic time series annual data were collected. Using panel data regression analysis, the results revealed that commercial bank has significant impact on SMEs' financing.

Nwosa and Oseni (2013) examine the impact of banks loan to SMEs on developed production in Nigeria for the period with a leg on each side of 1992 to 2010. Employ error alteration modeling method, the study deduce that bank loans to the SME sector had important impact on developed output both in the long and short run.

But the findings of Omah, Duruwoju, Adeoye and Elegunde (2012) did not follow the same. Their study examined the impact of post-bank consolidation on the performance of SMEs in Nigeria, with special reference to Lagos State. A sample size of 50 was drawn from the supra-population of the study within Ikeja Local Government in Lagos State. Apply mean, normal divergence and coefficient of variation in its data analysis, the study exposed that SMEs do not have better access to finance from side to side banks, due to neo-reorganization in banks as a result of post-bank consolidation and SMEs do not have total rapport with the financial organization due to their financial backdrop in Nigeria.

Dada (2014) noted that the time after time repeated grievance of SMEs about their problem concerning access to finance is highly relevant restraint that endangers the growth of the sector in Nigeria and investigating the effect of deposit money banks' credit on SMEs development employing Ordinary Least Square (OLS) technique to estimate the multiple regression models. The findings revealed that deposit money banks credit to SMEs and the saving and time deposit of deposit money banks exert a positive and significant influence on SMEs growth substitute by extensive and retail trade output as a part of GDP, while replace rate and interest rate exhibit adversative effect on SMEs growth.

Mamman and Aminu (2013) tax the result of 2004 banking reform on loan finance of SMEs in Nigeria. A sample size of 500 was randomly chosen and chi-square test was used which indicated that there is no significant effect of 2004 banking reform on loan financing of SMEs in Nigeria and suggested that there are some constraints which restricted access to loans from the banks for SMEs in Nigeria. Aliyu and Bello (2013) examined the contribution of deposit money banks to the growth of SMEs in Nigeria between 1980 and 2009. Using ratio analysis and trend analysis, it was discovered that deposit money banks contribute to financing SMEs but their contribution has declined as the government through CBN directives abolished the mandatory bank's credit allocations.

Imafidon and Itoya (2014) analyzed the contribution of commercial bank's loan to small scale enterprises on the growth of the Nigeria economy for the period of study (1993-2012). Co-integration and error alteration model move toward was used to approximation the association between the variables. The main judgment of this study was that the profitable bank's loan to small scale enterprises did not reveal any important effect on financial growth in Nigeria within the period of study. There is inverse finding the study of Rafiat and Ejededawe (2015) who examined the role of commercial bank in financing small scale enterprises in Ado Ekiti, Ekiti State using descriptive research design and correlation analysis revealed that there is a positive correlation between loans grants by banks and the growth and development of SMEs in Ekiti State.

Ogujiuba, Ohuche and Adenuga (2004) investigated the credit availability to small and medium scale enterprises in Nigeria by employing theoretical and statistical comparative cross sectional data found out that credit availability to SMEs in Nigeria is induced by external and internal factors. 


\subsection{Access to Finance by SMEs in Nigeria}

Access to finance had been factored in as one of the major challenges confronting the survival and growth of start-up SMEs in Nigeria (Eluhaiwe, 2016). According to Maas and Herrington (2012) quite a significant number of entrepreneurs are of the opinion that although there seems to be sufficient funds available, it remains difficult to access these funds, especially for start-up SMEs. The ability for the SMEs to grow depends highly on their potential to invest in restructuring and innovation, and all these investments require capital and therefore access to finance.

The development of robust SME sector would be a viable means to create job and alleviate poverty in Nigeria. Following years of Dutch Disease and loss in international competitiveness to this COVID-19 pandemic, the Nigerian SME sector is fragile, operating in a business environment that presents considerable challenges (e,g poor infrastructure, low skills, weak governance and corruption) So many SME operators in Nigeria have to provide electricity, water, security and even sometimes construct or rehabilitate roads within their area of operation in order to operate. The current situation whereby each industrial enterprise is compelled to provide its own electricity, water and, in some cases access roads to offset deficiencies in public infrastructural facilities, is detrimental to viability and efficiency in production. The effect on capital and operational costs also adversely affects the competitiveness of the national economy.

The World Bank Investment Climate Assessment (ICA) study (2008) identifies low access to finance as the second most important constraint for Nigerian SMEs, ranking after the electricity shortage. Only 5 percent of SMEs have a loan, despite the fact that 80 percent of them seek financing from the banks.

Owing to the inaccessibility of funds/loans from the banks by the SMEs, the Banker" s Committee of the Central Bank of Nigeria (CBN) initiated the Small and Medium Enterprises Equity Investment Scheme (SMEEIS) which required all banks to set aside 10 per cent of their profit after tax (PAT) for equity investment and promotion of small and medium enterprises. The funding was to come in the form of equity investment in eligible enterprises and or loans at single digit interest rate in order to reduce the burden of interest and other financial charges that arise under normal bank lending operations.

The SMEEIS was made voluntary, leaving the prerogative of participation to the banks. It was not surprising to find out that only a handful of banks chose to actively participate in the scheme, in numbers that were insufficient to meet the funding needs of SMEs in the country at that time. Funding for the scheme was based on PAT from banks (Okonkwo and Obidike, 2016). It is on record that for the year ending 2009, several banks recorded losses following the requirement that the banks account for non-performing loans in their accounts. With losses being made, certainly, there would be no contributions from such banks for that year.

As initially noted, SMEs have played important roles in the development process in most developed economies, and have proved to be the most viable engines of economic growth and development, a potent tool for employment generation and poverty reduction.

\subsection{Bank Funding and SMEs in Nigeria}

As earlier stated, banks in Nigeria have been accused of not providing enough funding for SMEs development in Nigeria. Even when the regulatory authority like Central Bank of Nigeria (CBN) has at various times mandated or appealed to banks in Nigeria to increase their funding to SMEs, the trend has not changed. It is pertinent to note that banks are in the business to make profit while at the same time adhering to rules of the regulatory authorities. Empirical evidence shows that financing contributes about $25 \%$ to the success of SMEs in Nigeria (Ogujuiba, Ohuche, and Adenuga, 2004). A World Bank report showed that $39 \%$ of small scale firms and $37 \%$ of medium scale firms in Nigeria are monetarily forced. Many SMEs in Nigeria lack the capital to continue their business and they are forced to wind up because they are unable to access the required funds. 
The inadequate financing for the SMEs is traceable to among other reasons the reluctance of banks to extend credits to them for the following reasons; Inadequate collateral by SMEs operators, weak demand for the products of SMEs as a result of the dwindling purchasing power of Nigerians, lack of patronage of locally produced goods and poor management practices by SMEs operators.

According to Eluhaiwe, (2016), Ogujiuba, Ohuche and Adenuga (2004) some other reasons why banks hardly lend to Nigeria SMEs are as follows:

1. Perception: This is the uncertainty banks have when processing loans for SMEs. Green (2003) argued deposit money banks tend to impute high risk to small enterprises and are therefore reluctant to extend credit to them. Due to their small size and inherent vulnerability to market fluctuations, the mortality rates of SMEs are relatively high. Banks in view of this see SMEs as a high risk and possible high defaults if credit is extended. This therefore may lead to poor assessment and disqualification of loan request by SME operator especially the loan amount is high amount or for a start up.

2. Inadequate of infrastructural facilities. Many banks blame their inability to fund SMEs on the economic climate prevalent in the country, citing for instance the low performance of public utilities as one of the factors threatening fund managers (Olanrewaju, 2001). The point is that the state of infrastructure in Nigeria is unacceptable. Electricity generation is unstable, inadequate and erratic. New roads are neither constructed nor old roads maintained; water supply is not sustainable etc. For banks to extend credit to SMEs, all these factors considered. At the end, it is realized that the cost of doing business in Nigeria is so high that the ability of the banks to recoup their investment is uncertain. The relative burden of such extra costs is much heavier on SMEs. The costs of providing such facilities to forms sometimes erodes up to 40 percent of the total sum expected for industrial take-off and the effects of the setback of such cost warrants, remain the firms indefinitely.

3. Poor understanding of the sector:- A number of relationship managers and credit officers have a little or no understanding of the SMEs sector. This limits their capacity to analysis and package loans as they are not equipped with right technical know-how for the exercise. Worse still, many Nigerian banks do not have SMEs desk that are manned by experts thus unable to access and price the risk elements.

4. High default rates from government- driven lending programs. Many SME operations who have participated in government sponsored programmes did not repay their loans as and when due. This has made banks to be wary about extending credit to them as they might make loan default a habit.

5. Information asymmetry. This exists where one party has more or better information than the other. This creates imbalance of power in transactions between the SME operators and the banks which can sometimes lead to failed or unsuccessful transactions.

6. Lack of collaterals: Collateral is a property or other assets that a borrower offers as a way for a lender to secure the loan. If the borrower defaults in the payment arrangements, the lender can seize the security to recoup its losses. This is an important prerequisite for credit in Nigeria. Unfortunately, many SME operators lack adequate collaterals to mortgage to enable them access bank loans (Ayuba and Zubairu, 2015)

7. Financial indiscipline: The problem of financial indiscipline has been highlighted as the major cause of the inability of SMEs to access funds from the banks. Firms are most likely to divert funds meant for the business in funding other projects. This naturally will impact on the survival ability of the business and equally compromise the ability of the firm to pay back the loan. 


\subsection{Conclusion and Recommendations}

The study was aimed at investigating the reasons why banks are reluctant in funding Small and Medium Enterprises in Nigeria. The study reveals that banks provide finances to SMEs, but a decline has been recorded over the years which made impossible for the SMEs sector to contribute meaningfully to economic growth of Nigeria. However, it was observed that banks in Nigeria are not in lack of fund and are willing to provide necessary funds needed by SMEs but so many factors have hampered their ability to do so. Banks and other financial institutions are unwilling to do business with Small and Medium Enterprises because they perceived them as high-risk ventures. Banks as a business entity has to make profit and maintain enough liquidity to meet up with other obligations of other stakeholders. Again the inability of the banks to extend the needed credits to the SMEs is attributable to the environment in these SMEs operate which does not support and encourage their survival.

The environment for doing business in Nigeria should be improved by the government most especially the electricity generation. So many Small and Medium enterprise operators in Nigeria have to provide electricity, water, security and even sometimes construct or rehabilitate roads within their area of operation in order to operate. The current situation whereby each industrial enterprise is compelled to provide its own electricity, water and, in some cases access roads to offset deficiencies in public infrastructural facilities, is detrimental to viability and efficiency in production. Again, the Central Bank of Nigeria (CBN) should train and retrain bank officers on the essentials and peculiarities of small and medium enterprises. These bank officers should man SMEs desk in their respective banks and help SME operators in their business plans.

\section{References}

[1] Abiola, B., Iyoha, F, and Joseph, T. (2011): "Microfinance and Micro, Small and Medium Enterprises Development in Nigeria" Unpublished Article, Covenant University, Ota, Ogun State, Nigeria.

[2] Adewale, A.A (2007) Promoting Medium and Small Scale Industries In Nigeria; The Partnership Option Between Government And Private Sector Entrepreneurs. The Nigerian Banker, journal of the chartered institute of bankers of Nigeria April-June

[3] Afolabi, M. O. (2013). Growth effect of Small and Medium Enterprises (SMEs) Financing in Nigeria, Journal of African Macroeconomic Review.3(1):193-205

[4] Aliyu, S.M. and Bello, G.B (2013): An Assessment of the Contribution of Commercial Banks to the Growth of Small and Medium Scale Enterprises in Nigeria. International Journal of Research in Social Sciences, 2(4), 47-55.

[5] Ayeni-Agbaje, A. R. and Osho, A. E.(2015) Commercial Banks Role In Financing Small Scale Industries In Nigeria (A Study Of First Bank, Ado-Ekiti, Ekiti State) European Journal of Accounting, Auditing and Finance Research Vol.3, No.8, pp.52-69, August. Published by European Centre for Research Training and Development UK (www.eajournals.org) 52 ISSN 2053-4086(Print), ISSN 20534094(Online)

[6] Ayuba B. and Zubairu M ( 2015) Impact of Banking Sector Credit on the Growth of Small and Medium Enterprises (SME's) in Nigeria. Journal of Resources Development and Management www.iiste.org ISSN 2422-8397 An International Peer-reviewed Journal Vol.15,

[7] Babafemi1 I,D, Adesheye I.M and Akure Z.B (2015) Small and Medium Scale Enterprises Financing and Development in Nigeria: A Critical Assessment Journal of Finance and Bank Management June 2015, Vol. 3, No. 1, pp. 190-198ISSN: 2333-6064 (Print), 2333-6072 (Online)

[8] Berger, A. N. and Udell, G. F. (2004) A More Complete Conceptual Framework for SME Finance. A Paper presented at the World Bank Conference on Small and Medium Enterprises: Overcoming Growth Constraints World Bank, MC 13-121, October 14-15.

[9] Dada, R. M. (2014), Commercial Banks' Credit and SMEs Development in Nigeria: An Empirical Review. International

[10] Eluhaiwe N (2016) How Micro Small and Medium Enterprises (MSMEs) Can Leverage on Central Bank of Nigeria's Real Sector Initiatives. Bullion. Publication of Central Bank of Nigeria Vol. 40 No. 2, April-June

[11] Gbandi, E.C. \& Amissah, G. (2014). Financing options for Small and Medium Enterprises (SMEs) in Nigeria. European Scientific Journal, 10(1), 327-340.

[12] Imafidon K. and Itoya $\mathbf{J}(2014)$ An Analysis of the Contribution of Commercial Banks to Small Scale Enterprises on the Growth of the Nigeria Economy. International Journal of Business and Social Science Vol. 5, No. 9(1); pg 256 Journal of Research (IJR) 1(8): 305-320. 
[13] Kadiri, I.B. (2012). Small and Medium Scale Enterprises and Employment Generation in Nigeria: The Role of Finance. Kuwait Chapter of Arabian Journal of Business and Management Review, 1(9): 79-94.

[14] Mamman, A. \&Aminu, K.S. (2013). Effect of 2004 Banking Reforms on Loan Financing of Small and Medium Scale Industries in Nigeria. International Journal of Small Business and Entrepreneurship Research, 1(3), 44-53.

[15] Meyanathan, S.D. (1994), "Industrial Structures and the Development of Small and Medium Enterprise Linkages: Examples from East Asia". The World Bank.

[16] Oboh, G.A. (2004) "Contemporary Approaches for Financing Micro, Small and Medium Enterprises". Conference on SME held at the International Conference Centre, Abuja, Nigeria, July 19 - 22, pp. 2-15.

[17] Odeh, O. (2005), "The Impact of Federal Government Reform Programme on the Development of the SMEs Sector". A paper presented at the National Seminar on "Facilitating Easy Accessibility to the SMEEIS Funds bySME operators. Lagos, 10 - 11, October.

[18] Ogujiuba K.K, Ohuche F.K and Adenuga A.O,(2004) Credit availability to small and medium scale enterprises in Nigeria: importance of new capital base for banks. Bullion, Publication of the Central Bank of Nigeria vol.28. no.4

[19] Ohachosim, C.I., Onwuchekwa, F.C. \&Ifeanyi, T.T. (2013). Financial Challenges of Small and Medium-Sized Enterprises (SMEs) in Nigeria: The Relevance of Accounting Information. Review of Public Administration and Management, 1(2), 248-276.

[20] Oke, M.O. and Aluko, O.A.( 2015) Impact of Commercial Banks on Small and Medium Enterprises Financing In Nigeria. IOSR Journal of Business and Management (IOSR-JBM) e-ISSN: 2278-487X, p-ISSN: 2319-7668. Volume 17, Issue 4.Ver. I PP 23-26 www.iosrjournals.org DOI: 10.9790/487X-17412326 www.iosrjournals.org 23

[21] Okonkwo, N.O and Obidike, C.P (2016) SmallandMedium Scale Enterprises Financing In Nigeria: Problems and Prospects. International Journal of Innovative Social Sciences \& Humanities Research 4(1):77-86,

[22] Omah, I., Durowoju, S.T., Adeoye, A.O. \&Elegunde, A.F. (2012). Post-Bank Consolidation: A Debacle in the Survival of SMEs in Nigeria "An Empirical Study". Australian Journal of Business and Management Research, 2(8), 1-6.

[23] Onugu, B.A.N. (2005). Small and Medium Enterprises (SMEs) in Nigeria: Problems and Prospects (Ph.D Dissertation). St. Clements University.

[24] Onwumere, J (2000). The Nature and Relevance of SMEs in Economic Development. (CIBN).The Nigeria Banker October , P 17

[25] Osoba, A. M. (1987). Small-Scale Enterprises in the Development Process, In Osoba, A.M. (Eds.). Towards the Development of SmallScale Industries in Nigeria, NISER, Ibadan. PP. 8-24.

[26] Osotimehin, K.O. Jegede, C. A and Akinlabi, B. H (2012) An Evaluation of the Challenges and Prospects of Micro and Small Scale Enterprises Development in Nigeria. American International Journal of Contemporary Research Vol. 2 No. 4; pg 174

[27] Rafiat A. A and Ejededawe O.A (2015) Commercial Banks Role In Financing Small Scale Industries In Nigeria (A Study Of First Bank, Ado-Ekiti, Ekiti State) European Journal of Accounting, Auditing and Finance Research Vol.3, No.8, pp.52-69, Published by European Centre for Research Training and Development UK (www.eajournals.org)

[28] Soludo, C. C. (2008). Making finance work for the poor: A convocation Paper retrieved from http://www.cenbank.org/documents/speeches

[29] Tolentino, A. (1996), "Guidelines for the Analysis of Policies and Programs for Small and Medium Enterprise Development Enterprise and Management Development". ILO Working Paper.

[30] Ukpabio, S.A. (2004), “Development of Small Scale Sector, What Role for the Federal Government Nigerian Banker”, Vol. 17 , No. 1.

[31] United Nation Industrial Development Organization: UNIDO (2012): "Corporate Social Responsibility: Implications for Small and Medium Enterprises in Developing Countries". Vienna. Retrieved from internet on 1st June 2014 at

[32] Uzor, O.O. (2004). Small and Medium Scale Enterprises Cluster Development in South-Eastern Region of Nigeria. Institute for World Economics and International Management, pp. 5-15. www.unido.org/fileadmin/user_media/ 